\title{
Enriching the Learning Experience: a CALM Approach
}

\author{
Dr Carol Johnston and Dr Nilss Olekalns * \\ Faculty of Economics and Commerce \\ University of Melbourne \\ Victoria, 3010 \\ Australia \\ c.johnston@ecomfac.unimelb.edu.au \\ n.olekalns@ecomfac.unimelb.edu.au
}

Correspondence to:
Dr Carol Johnston
Teaching and Learning Unit
Faculty of Economics and Commerce
University of Melbourne
Victoria, 3010
Australia

${ }^{*} A$ preliminary version of this paper was presented at the EAIR Forum, Freie Universitätat, Berlin, September 2000. We like to thank participants at the Forum for their comments. Any errors are our responsibility. The project was funded by a grant from the University of Melbourne's Teaching and Learning (Multimedia and Electronic Learning Technologies) Committee. Mr Mark McCrohon (Teaching and Learning Unit, Faculty of Economics and Commerce, University of Melbourne) undertook the programming for the project. 


\begin{abstract}
This paper outlines and evaluates a new learning strategy implemented in the Faculty of Economics and Commerce at the University of Melbourne. The strategy is an Internet based assignment delivery and assessment system designed to (i) equip students to make the link between macroeconomic theory and important real-world issues, (ii) develop positive attitudes to the subject iii) develop deep approaches to learning (iv) develop a facility for critical analysis and problem solving and v) develop effective study habits. Using a multi-dimensional evaluation strategy, the indications are that the new approach has succeeded in its aims.
\end{abstract}




\section{INTRODUCTION}

In this paper, we describe an Internet-based, subject delivery and assessment system, Critical and Analytical Learning in Macroeconomics (CALM) and report the results of an evaluation of its impact on learning outcomes. The system was introduced into a compulsory first year macroeconomics unit in the Faculty of Economics and Commerce at the University of Melbourne in 1999, and then subsequently refined, improved, and used again in 2000. This unit attracts enrolments of around 1200 students.

CALM aims to encourage positive attitudes towards macroeconomics, deeper approaches to learning and confidence in critical thinking skills. The project's design is based on the assumption that the achievement of these aims is more likely when students reflect on their own learning, where the stimulus for learning is real world problems and issues, and where assessment rewards the ability to analyse, synthesise and critically evaluate complex material.

CALM places particular emphasis on encouraging appropriate study skills and the capacity to apply knowledge in a variety of contexts as well as on the development of confidence in using the new electronic teaching and learning technologies. The principle aim has been to improve the quality of both the level and the type of learning outcomes.

\section{BACKGROUND}

Several elements of the current Higher Education environment have provided the context for the development of the CALM system. Among these are; the need to develop a closer relationship between academics' and employers' respective views of the skills required by graduates; the encouragement of deeper approaches to learning and lifelong 
learning; issues related to the transition of students from school to university; and finally effective use of electronic technologies to enrich the student learning environment. ${ }^{1}$

\section{Approaches to learning}

Educators have been keenly aware for at least the last decade that student learning outcomes are enhanced when there is a recognition of the interrelatedness of teaching methods employed with the learning styles and approaches to learning of students (Entwistle and Ramsden 1983). Qualitative differences in student learning can result from students' personal attitudes towards a learning task and the context in which the learning occurs.

This is most clearly articulated in the differences that exist between deep and surface learning (Marton and Saljo 1976). Students who use a deep approach are personally involved in the learning task and seek to obtain some underlying meaning. In addition they aim to understand relationships between the immediate task and other tasks or contexts. Such students are likely to read extensively around a given topic, are motivated to discuss the topic with others, and ultimately achieve higher grades on assessment tasks (assuming the assessment instrument is designed to assess more than a simple recall of facts) than students who use a surface approach (Biggs, 1987, 1989,1999).

A surface approach to learning, arises when the student sees learning as a means to achieve a short term goal which may be simply to do enough work to pass an

\footnotetext{
${ }^{1}$ We know from surveys that employers often perceive that graduate job applicants lack a capacity for independent, critical thinking, problem solving skills and a capacity for clear oral and written communication (DEETYA 2000, Dearing 1997). Students report that they want subjects that relate theory to real world problems and also mechanisms that provide early, detailed feedback on their progress (Mclnnis and James 1995).
} 
assessment hurdle. Students who adopt this approach are motivated by an extrinsic objective and will commit unrelated facts to their short term memory, but are unlikely to be able to establish meaning or relationships between or within given tasks. The student is dependent on the teacher and is unlikely to achieve highly on assessment tasks that are designed to test higher order thinking (Biggs, 1987). ${ }^{2}$

The CALM project aims to foster a deep approach to the learning task. With this in mind, CALM uses an "issues based" approach to assignment work. Students are presented with background information relating to a particular event drawn from contemporary experience. Where possible, the event is something that (i) has occurred in the very recent past (sometimes in the same week as when the assignment is made available to students) and (ii) is amenable to analysis using the theoretical tools developed in the lecture and tutorial program and in the set text. The aim is to encourage students to see the practical usefulness of their course material and to equip them to make more sense of current economic events.

CALM also builds on studies which show that an individual student's achievement is consistently and positively related to the level of help that the student gives to others (Slavin 1990 and Palinscar and Brown 1984). The CALM system provides the opportunity to interact in a structured way with peers through reading other students' work and commenting upon it. This process compels students to externalise their thoughts and make their ideas explicit. Enhanced understanding results because

2 Biggs (1979; 1987) and Entwistle and Ramsden (1983) have proposed a third approach to learning, the so-called 'achieving' approach. The student using this approach is motivated extrinsically and creates a highly organised, productive approach to their learning. These students work to achieve grades that fit in with their egos or career aspirations. They have studied the game carefully and adjust their learning according to the rules as they perceive them. 
students must think about the material and develop and structure explanations. Other benefits of students interacting directly with their peers about their learning include improved communication skills, increased individual self-confidence and new levels of openness to ideas. Strategies for active learning of this kind have been widely documented (see, for example, Meyer \& Jones 1993).

Assessment is a powerful tool to stimulate a deeper approach to learning. Ramsden (1992 p67) argues that "The methods we use to assess students are one of the most critical of all influences on their learning" (see also for review Marton et al 1984). The amount and type of assessment that students are asked to undertake will influence their approach to learning. If they are assessed too much and if the thinking skills that are assessed are of a lower order students will respond by adopting a surface approach to learning in preparing for such assessment tasks. CALM uses assessment as a vehicle for the encouragement of deeper approaches to learning. The form of assessment is designed to encourage students to reflect on their learning and to encourage them to seek meaning in relation to the CALM tasks. Surface level learning is not rewarded or encouraged by the CALM approach.

\section{Critical thinking}

Critical thinking encompasses a number of key elements, among them a capacity to work with ambiguity and to recognise that issues can be viewed from many different perspectives. Individuals who have developed the capacity for critical thinking are predisposed towards independence and autonomy. These individuals are able to apply principles and theories learned in one context to a different context. 
Critical thinking is a key pedagogical goal of the CALM project. However, explaining to students what we mean when we use the concept is problematic. There have been numerous articles that attempt to define critical thinking (see for example Johnson 1992, Feeley 1976, Feiner and Roberts 1995) each of which emphasises different aspects of the concept. The CALM project has broadly adopted an operational approach in so far as the following elements of critical thinking are used in assessing student work. The students should be able to 1) distinguish between positive and normative statements, 2) determine the reliability of a source, 3) determine the factual accuracy of a statement, 4) distinguish the relevant from the irrelevant, 5) identify unstated assumptions, 6) identify inappropriate use of assumptions and ambiguous arguments, 7) recognise logical inconsistencies in the line of reasoning and 8) determine the strengths of an argument.

\section{Transition Issues}

The early experiences of undergraduate students are important in terms of establishing attitudes, outlooks and learning that they take with them throughout their course and into their work environment. The losses incurred when students do not make this transition successfully are great. McInnis and James (1995) report in their study of Australian first year students that managing the workload was a key factor in contributing to a satisfactory transition and that feedback on progress was of crucial importance to all first year students.

These issues were addressed in the design of the CALM project. Firstly, the project design assumes that students learn more effectively and at a deeper level if they work consistently throughout the semester rather than cramming for an examination at the end. Yet, incoming students often find it difficult to develop these consistent work habits. In order to address this, CALM operates for ten of the twelve semester weeks. Secondly, 
CALM provides students with earlier, more detailed feedback on their progress. Finally, CALM recognises the need to develop in first year students confidence in their computer related and Internet related skills that they use in later years of study and in the workplace.

\section{Internet-based teaching technologies}

Face to face teaching is only one of the means by which learning is brought about and is decreasing in importance with the rise of more flexible, electronically distributed, open, learner controlled forms of learning. Some of the advantages of on-line delivery of elements of subjects are the increased interaction between students and other students and students and staff in terms of both the quantity and intensity of the interaction; better access to group knowledge and support, a more democratic environment where students respond to content rather than to personalities; convenience of access and, for many, increased motivation, (Harasim et al, 1997, Laurillard, 1993). The asynchronous nature of on-line interactions allow students time to reflect on a topic before completing an on-line task.

\section{THE CALM PROJECT ${ }^{3}$}

Introductory Macroeconomics at the University of Melbourne is taught in two, one-hour lectures per week and one tutorial, typically of 18 students, over a twelve-week semester. There are approximately 1200 students enrolled each year. The lectures are taken by the same lecturer, are repeated three times on the same day, and each lecture commonly has 400 students attending at a time. The tutorials are organised on a Collaborative Problem Solving (CPS) basis whereby students are further divided into 
groups of four to solve previously unseen problems based on pre-reading exercises (Johnston et al, 2000). Each student is a member of a 'live' tutorial as well as an on-line tutorial composed of the same students. Assessment comprises an examination (70 per cent), tutorial participation and attendance (10 per cent) and CALM responses and critical comments (20 per cent).

\section{Components}

The CALM system comprises several interrelated components; the issues page, the online tutorial group's responses and comments pages, the on-line tutor and the individual student's page for private messages from the 'on-line' and 'live' tutors and assessment results and comments. ${ }^{4}$

\section{Process}

In the first week of the semester all students are assigned to their 'live' CPS tutorial and the CALM on-line tutorial. Three macroeconomic issues are posted to the 'Issues' page over the course of the semester; one at week two, one around week 5 and one at week $8^{5}$. Students are asked to respond to each issue. This requires the student to apply the economic theory developed in lectures and 'live' tutorials to the issue. All responses are

\footnotetext{
${ }^{3}$ All programming for CALM was undertaken by Mr Mark McCrohon of the Faculty of Economics and Commerce Teaching and Learning Unit. Commercial software was found not to be suitable for our purposes.

${ }^{4}$ A demonstration module, which allows users to experience CALM from the perspective of a student, can be found at

http://www.tlu.ecom.unimelb.edu.au/calmDemo/student.

Users of the demonstration module should follow the audio links, in numerical order, in over to navigate the system.

5 In 2000, these issues involved (i) a discussion and application of the criteria used to rank countries' macroeconomic performance, (ii) a rationalisation of an apparent contradiction in two newspaper articles published on the same day, one reporting on Australia's high rate of economic growth, the other reporting on a major slump in Australia's housing construction industry and (iii) explaining why the value of the Australian dollar against the U.S. dollar fell immediately after the release of National Accounts figures confirming Australia's high rate of economic growth.
} 
electronically submitted to the CALM 'Responses' page. Students can edit and change their own responses up to the submission date. After this date all students in their respective tutorials can view all of the responses derived from that tutorial. Student identification is removed when responses appear on the responses page to allow for privacy concerns. The display of the tutorial members' responses provides students with useful feedback on the standard of their own work in relation to others in the tutorial and also allows them to see the range of responses to the same issue that are possible.

The next stage in the process is designed to develop reflective and critical thinking skills in students. Students read the responses posted for their tutorial group and select and reserve one response on which to critically comment. Students are provided with a list of criteria on which to base their comment and a sample critical comment on which to model their work. Following final submission, all responses and comments are available for all CALM tutorial members to view. This process is repeated for each of the three issues, meaning that students submit a total of six pieces of work during the semester (three responses and three comments) at intervals of around two weeks.

At the end of each issue, responses and comments are assessed and results posted to the student's individual CALM page so that students have a record of how well they are performing. The first issue carries relatively less weight than the other two issues in the overall assessment of the subject to allow students to become familiar with the system.

Feedback to students is provided in a number of forms. Students receive a mark on their response and comment; are able to view other students work in their own tutorial; can view model responses and comments provided by the lecturer; are provided with the on- 
line tutor's overview report at the end of each issue; and can obtain individual personal comment from their tutor who has assessed their work. The learner is expected to take an active role in the feedback process through self reflection and comparison with others work and the model responses.

\section{The On-line tutor}

An on-line tutor, known as the Webmaster, is available to all students through CALM. Students can ask questions of the Webmaster at any time and typically, these will be answered within a 24-hour period. The questions and answers are posted to a CALM bulletin board for all students to see. This allows all students to have access to the information, not just the student who posed the question. Questions are identified by topic so that students can refer to the Webmaster bulletin board when they are revising for examinations or completing an assignment. Students can ask questions when they think of them at any time of the day or night and it does not require them to come into the university. The Webmaster can also post messages to individual students as well as to all students enrolled in the subject. The appointed Webmaster also takes a live tutorial in the subject and is encouraged to attend the lectures so that he or she is familiar with all aspects of the subject delivery.

\section{Assistance to tutors and students}

Students are provided with information on how to use the CALM software in a variety of forms. Paper copies of instructions are provided at the start of semester and Internet help instructions are available at each step of the CALM system. In addition a short demonstration of the system is provided at the start of lectures in the first week of semester. A more detailed demonstration is conducted a week later at lunchtime for students who feel that they need further illustration of the system. In addition a tutor is 
made available for those students using the computer laboratory on the day of submission of responses and comments in case students experience difficulty. All 'live' tutors are trained in the use of the system from the administrative point of view, particularly in relation to their submission of marks and comments to individual students, which are made through an "academic" module built into CALM.

\section{EVALUATION}

CALM has been evaluated in a variety of ways. Students completed a survey at the start and end of the semester, they also completed a university wide Quality of Teaching survey and tutors were interviewed. We report briefly on the results of each of these forms of evaluation based on the operation of CALM in Semester 2, 2000.

\section{On-line Survey}

Students completed the first survey, on-line, as a prelude to beginning work on their first CALM assignment in the second week of the semester and the second survey, also online, in the tenth week of the semester prior to submitting their comment for their third CALM assignment. The first survey was completed by 1078 students and the second by 1046 students.

The survey is divided into four sections. In the first section, the students were questioned about their language background, whether they had completed Introductory Microeconomics, a pre-requisite subject for Introductory Macroeconomics, in the previous semester, and their use and perception of the Microeconomics subject home page on the Internet. ${ }^{6}$ The second section of the survey asked students to rate their

\footnotetext{
${ }^{6}$ The first section of the second survey differed only in so far as students were asked about their use and perceptions of the Introductory Macroeconomics home page.
} 
confidence in relation to key skills. In the third section students were asked to report on their attitude to macroeconomics and aspects of their learning approach in the subject. Statements in this section that relate to student attitudes to macroeconomics are drawn from the Attitudes to Macroeconomics dimension of the Survey on Economic Attitudes (SEA) instrument developed for the US Joint Council of Economic Education, (Soper and Walstad 1983). Statements that relate to deep learning are drawn from the Approaches to Study Inventory (Entwistle and Ramsden 1983). Other statements that relate to collaboration, consistency of work, feedback and relevance have been designed specifically to evaluate performance in relation to other objectives of the CALM project. The fourth section asked students to provide an open-ended comment on any aspect of the CALM project.

\section{Section 1 Background}

Results of the first section of the pre and post surveys are reported in Table I. The table shows that the cohort is almost evenly split between males and females with students from non-English speaking background comprising around 40 percent of the respondents. Nearly 90 percent of respondents had completed the Microeconomics prerequisite subject in the preceding semester. There is an interesting difference in the students' perceptions of the usefulness of the home pages in the two subjects. Introductory Microeconomics did not use Internet-based assessment systems such as CALM, preferring to use its home pages as a repository for lecture materials (including copies of the overhead slides used in lectures). Students from non-English speaking backgrounds were more likely than English speaking background students to associate this with an improvement in subject delivery. The Introductory Macroeconomics homepage was the gateway for students into CALM. Lecture notes or slides were not made available to students. In contrast to the Introductory Microeconomics course, there 
is very little difference between English and non-English speaking students as to their perceptions of whether the Introductory Macroeconomics homepage improved subject delivery. Both English and non-English speaking students in Macroeconomics used the Internet subject pages more in second semester and, relative to the first semester, students were more likely to report that use of the subject home page improved their perception of subject delivery.

Table I about here

\section{Section 2 Skills confidence}

The second section of the survey asked students to rate their confidence in relation to key skills using a scale ranging from "always confident" (with a numerical value of 4) through to "never confident (with a numerical value of 0 ). Results of this section are reported in Table II.

Looking first at the results for the entire class (ie. English and non-English speaking backgrounds combined), the table shows that students reported high levels of confidence in their computer related and Internet related skills and these appear to have improved over the course of the semester. Mann-Whitney tests for the equality of the pre and post means easily rejected the null hypothesis for both computer and Internet related skills in favour of the one-sided alternative that the "post" mean score was higher. For the computer-related skills, the test statistic was 6.08 while the test statistic for Internet confidence was $6.55 .^{7}$ These results also extended to the English speaking and non-English speaking background students when the groups were analysed separately. For the English speaking background students, the Mann-Whitney test

\footnotetext{
${ }^{7}$ Under the null hypothesis of equality of the means, the Mann-Whitney test statistic has the standardised normal distribution.
} 
statistics are, respectively, 3.90 and 4.96 while the corresponding test statistics for the non-English speaking background students are 5.00 and 4.43 . All of these test statistics are significant at the 5 per cent level.

The students' perception of their critical thinking abilities also increased over the course of the semester. The Mann-Whitney test statistics were, respectively, 2.89 (entire class), 2.14 (English speaking background) and 2.14 (non-English speaking background). These statistics, which are all significant at the 5 percent level, are consistent with CALM having achieved one of its key aims, namely to produce an improvement in students' confidence in applying critical analysis to complex problems.

Table II about here

This improvement was not as apparent in the students' perceptions of their problem solving skills. The Mann-Whitney test statistics for this question were, respectively, 1.67 (entire class), 1.35 (English speaking background) and 1.10 (non-English speaking background). Of these, the first two are significant, albeit at only the ten percent level.

\section{Section 3 Attitudes, approaches and experiences}

Table III shows the results from the third section of the respective surveys, where students were asked to report on aspects of their attitudes and learning approach. The students were given a series of statements and then asked to indicate whether they "strongly disagree", "disagree", are "uncertain", "agree" or "strongly agree". Their answers were scored using a scale ranging from 0 (for strongly disagree) through to 4 (for strongly agree).

Table III about here 
Considering first the entire class, the results indicated an improvement in attitudes towards macroeconomics over the course of the semester. There were significant improvements in the mean scores for statements related to the practical application of macroeconomics and students were more likely to report that macroeconomics is one of their favourite subjects. Students' enthusiasm for macroeconomics seems to have increased, in particular with regard to their willingness to read unassigned macroeconomics material and with their level of enjoyment when reading about macroeconomics topics. Students were more likely to report that they found macroeconomics less boring and less of a waste of time by the end of the semester. Students appeared to be more aware of the relevance of macroeconomics as there were significant increases in the mean scores for statements that related to students' use of macroeconomics in analysis and their recognition of the relevance of macroeconomics to real world situations. Students indicated that they worked more collaboratively in that they were significantly more likely to report that they discussed macroeconomics and that they valued what other students had to say. Finally students were more likely to report that they received sufficient feedback on their progress in macroeconomics than in first semester microeconomics.

Deep approaches to learning as measured by student responses to the statements in this section of the survey showed no change. Similarly there was no change in student responses to the consistent study statements in this section of the survey although a positive response in this regard is apparent in other elements of the evaluation.

For the most part, there was a common pattern of responses across English and nonEnglish speaking background students. However, there were some differences; English speaking background students were more likely to rate macroeconomics as one of their 
favourite subjects and value what other students said in class in the post survey results. Non- English speaking background students were less likely to see macroeconomics as a waste of time and were more likely to see macroeconomics as practical.

Table IV about here

\section{Section 3a second survey}

In the second survey, students were also asked to evaluate their direct experiences with CALM. These results are presented in Table IV. Once again, the students were given a series of statements and then asked to indicate whether they "strongly disagree", "disagree", are "uncertain", "agree" or "strongly agree". The results were consistent with students having found CALM to be an easy system to use. Three quarters of the sample either agreed of strongly agreed with the statement that CALM encouraged a consistent work pattern through the semester. Around 60 per cent of the sample agreed or strongly agreed that their critical and problem solving skills improved during the semester and that they learned from reading the responses of their peers and valued their feedback.

\section{Section 4 Open ended comments}

In the first survey 188 comments were received and in the second 306 . First survey comments largely related to student perceptions developed in first semester. There was evidence of concern about feedback, relevance, difficulty, computers and the need to work more consistently. Typical comments were:

Feedback

I was told very little about how I was doing in Microeconomics last semester. It seemed as though you were by yourself completely and although it's good to push yourself, it would be nice to have had someone there to at least let me know if I'm on the wrong track altogether!

Relevance

I believe that the first year economics courses would benefit from increased emphasis on topical issues and problems perhaps through the use of newspaper articles in tutes or assignments. I believe this would help students to further relate economic study and 
theory to the 'real world' and provide increased motivation and interest in the topics and subject as a whole. (Student 2)

Difficulty

Macroeconomics is a paradox for me - I see the huge importance it has on the world yet its ambiguities and unknowns are particularly frustating. It claims it is a science yet has none of the empirical solid grounds of real sciences. (Student 3)

Computers

I hate computers and find the idea that it is complusory difficult especially if everything is on the "homepage". I have no access to the internet at home. That means I have to do it at uni during the day which I am not pleased about. (Student 4)

Study habits

Last semester the teaching staff were fantastic in their willingness to help students. Unfortunately I failed to fully utilise the help on offer throughout the semester and found myself "cramming" when it came to the exam and consequently got a result which didn't reflect my true capabilities. This semester I plan to keep up with the work and seek help when having difficulties. (Student 5)

Comments derived from the second survey indicated a positive response to the subject, a consistent approach to study, an appreciation of the real world application of the subject and the convenience of on-line assessment, an acknowledgment of the higher level of feedback and greater confidence in the use of the technology. Typical comments were:

\section{Feedback}

I think that the idea of CALM is good because it allows you to get feedback over a longer period and it's more spread out. You can get a clearer idea of what is expected of you.(Student 6)

\section{Relevance}

As a student who failed Macro a few years ago, and was very apprehensive about repeating it again, the CALM project has allowed me to critically think about macroeconomics and, more importantly, see macroeconomics in a real-world sense. In this way, I have gained unexpected satisfaction from this subject, have been able to apply theory to my part-time job in funds management, and generally gain confidence in my economic thinking. (Student 7)

Enjoyment

After struggling to understand, enjoy and pass Micro is semester 1, I was not looking forward to Macro. However, Macro has been my favourite subject this semester. I have enjoyed the structure of the subject. The way tutes are run and the CALM assignemnts helped me to understand the subject and forced me to work throughout the semester. (Student 8)

\section{Computers}

After initially being apprehensive about using the computer to hand in assignments, I have found it easy and relatively stress free. (Student 9)

Study habits

I think that CALM is a very interesting and extremely innovative scheme to really keep us slacker students on our toes and to actually keep abreast with whatever work that is being taught throughout the semester. It has been interesting especially when we had to deal with real world issues and try to figure it out by applying whatever meagre knowledge and common sense that we have. (Student 10) 
On-line tutor

Online tutor questions were very interesting to read, both the questions raised and the answers given. The online questions helped me think of other issues, ie. the issus raised by the other students. CALM also improved my interest in reading economic articles in the papers. (Student 11)

Convenience

CALM is good because you can get help and other students ideas to help through the online tutor. And also because you don't have to go to Uni to hand your work in. (Student 12)

These comments were largely consistent with the data from the first three sections of the surveys.

Negative comments primarily related to the fact that some tutors had not commented specifically on student work. While students recognised the value of other student's comments they still wanted the tutor to comment individually on their work. A typical comment in this regard was:

My biggest criticism of CALM would be that although we get a mark and criteria sheet, we don't receive any comments from our Tutor explaining why we got the mark that we did, or how we could have improved our response. Although a student receives feedback from another student, the respondent may often disagree or feel that they did not go into enough depth. I am sure the Tutor can still give you the best feedback, especially on areas where marks were lost.

In this regard there is still a way to go in encouraging some students to take advantage of the wide variety in forms of feedback that the CALM system allows. Response to statements 19 and 20 in Table 3 and 7 and 8 in Table 4 indicate however that the perception of feedbcak had improved over the semster for most students.

\section{2) University Quality of Teaching Survey results}

At the end of each semester as part of the university's regular quality of teaching evaluation, all students are requested to complete a survey in each subject. The results for Introductory Macroeonomics are reported in Table V. Introductory Macroeonomics was perceived more positively by students than any other first or second year subject in the department. While it is difficult to separate the factors that have contributed to this

Table V about here 
result it appears from statements 6 - 8 that the on-line materials, of which CALM was a significant part, were perceived by students to assist them in their learning.

\section{3) Interviews with tutors}

There were 22 tutors in this subject. Tutors attended a meeting with the lecturer every two weeks. As a regular part of the meeting tutors were asked to provided feedback to the lecturer on how students were reacting to the teaching programme including CALM. This provided some informal evidence of tutors' perceptions. In addition two tutors were formally interviewed at the end of the semster to obtain their views of how the CALM process operated in their tutorial groups. Tutor 1 was both a 'live' tutor as well as the online tutor. Broadly their observations of students correlated well with students' own perceptions of how they worked with the CALM system. Students were seen to be enjoying macroeconomics and to have a greater appreocation of its relevance

The strength of CALM is the practical nature of the macroeconomics issues that have been set. Students like learning about stuff that is relevant to them in their daily lives. Lets face it if you can't stimulate students in first year and make them want to learn then we have lost a fine opportunity. (Tutor 1)

In addition the tutors noted that the opportunity for cheating was sharpely reduced using this process. This reduction was seen as result of the fact that all student work is displayed in each on-line tutorial and other students are required to read it very carefully and comment on it.

The tutors also noted an improvement over the semester in student ability to critically analyse anothers work

Students approach to the critical comment improved over the semester. This demonstrated that students were reflecting on what they had written in their original response more than they had done in the past. Previuosly students would hand in a piece of work and then promptly forget about it. They would wait passivley for the tutor comment but were not actively engaged in the proces. (Tutor 2) 
Tutor 1 thought that students from non-English speaking background students were more likely to use the on-line tutor than English speaking background student. The reasons for this he believed related to cultural differences. In some cultures asking questions could be seen to show disrespect and students who were new to the country may not have developed networks of friends in the subject and were therefore more likely to make use of the 24 hour on-line tutor facility.

\section{IMPLICATIONS}

Given its multidimensional nature, it is difficult to pinpoint with any certainty exactly what it is about CALM that has produced the favourable outcomes documented above. We believe, however, that some valuable general lessons have been learnt from CALM about student approaches to learning and about pedagogical techniques that are capable of producing what we would regard as improved learning outcomes.

First is the importance of tying together abstract coursework with real world issues, and of using assessment as a motivational device to encourage students to develop for themselves the links between the two. There are many pay-offs to this. Students' mastery of the material increases as they are forced to reflect on their lectures and their reading in order to apply the material to real-world issues. Students also gain an appreciation of the practical usefulness of the discipline and this helps to foster a more positive attitude towards their studies.

We also believe that the emphasis on peer feedback in CALM has had a significant impact on our students. For many, this will have been the first time that they have been given open access to the work of their peers. The benefit of doing so is that it has 
enabled students to make an evaluation of how their work stands in relation to the work of their peers. In order to make sense of this information, students have to reflect on their own learning, and in doing so, adopt a cognitive approach that is allowing of selfcriticism. Students in CALM cannot rely on a tutor or lecturer to simply tell them where they have gone wrong, an extremely passive form of feedback, but are required to take on board some measure of responsibility for the feedback that they receive. Students also learn important critical skills as they reflect on the work of others, and develop a capacity to identify strengths and weaknesses in arguments and to offer constructive suggestions as to how the work of their peers might be improved.

Along similar lines, the Webmaster's bulletin board has provided a forum in which students can gain access to the concerns and questions of their peers and to see how those concerns and questions have been addressed. Tutors often report that despite their best efforts, many students find tutorials intimidating and are reluctant to ask or answer questions, presumably for fear of being revealed as a poor student. The anonymity provided by the bulletin board, and the opportunity to see that a particular question may have been troubling many other students, can, we believe, be quite empowering for many of our students.

The development of consistent work patterns is another aspect of CALM that we believe has made an important contribution to the program's success. The development of a consistent work effort is part of the process by which students gain a deep knowledge of the course material. By using an assessment instrument such as CALM, which requires a consistency of work effort throughout the semester, our students maintain a study schedule that allows them the opportunity to develop a deeper level of knowledge than would otherwise be the case. 
Students' satisfaction with the course improved because they valued the flexibility that an on-line assessment tool provides. In essence, CALM negated the need to journey into University in order to submit work by a deadline. It is clear from many of the openended comments on the second CALM survey, that many of our students saw this flexibility as being an extremely attractive feature of CALM. Likewise, the 24-hour availability of the Webmaster's bulletin board and the ability to ask questions and receive answers away from campus.

Finally, we did not find wide differences between English speaking and non-English speaking background students. Non-English speaking background students comprise over a third of the student body and so the provision of a learning programme suited to their particular needs is important. CALM appears to cater equally well for both language backgrounds.

These positive outcomes have only been possible with the use of the Internet technology. With a class size approaching 1200 , it would simply not be possible to give students access to the peer feedback provided by CALM if a "paper-based" system was adopted. Nor would it possible to provide students with assessable course assignments based on real-world events happening in the very recent past (printing lags alone mean that with 1200 students, paper based materials often have to be prepared well in advance of their distribution). The webmaster's bulletin board, of course, would also not exist were it not for the Internet.

Much has been gained from using the CALM system. Student's confidence in their abilities, both computer and Internet related, and in relation to their facilities for critical 
and analytical thinking, showed significant improvement, as did their approach to their studies and their perception of the practical usefulness of macroeconomics. Student attitudes to macroeconomics were more positive and given that the subject is compulsory this result is particularly satisfying. The evidence we have is that the CALM system is an effective way in which to assist students to learn and in which to foster the skills that we believe are required of graduates. 


\section{BIBLIOGRAPHY}

BIGGS, J. (1979) Individual differences in study processes and the quality of learning outcomes, Higher Education, 8, pp. 381-394.

BIGGS, J. (1987) Student approaches to Learning and Studying. Australian Council for Educational Research, Hawthorn, Vic.

BIGGS, J. (1989) Approaches to Enhancement of Tertiary Teaching. Higher Education Research and Development, Vol 8, No. 1, pp. 7-25

BIGGS J. (1999) Teaching for Quality Learning at University: What the student does. (Buckingham, The Society for Research into Higher Education and Open University Press).

DEARING, R. (1997) Higher Education in the Learning Society: Report of the National Committee of Inquiry into Higher Education (London: HMSO and NCIHE Publications).

DEPARTMENT OF EDUCATION TRAINING AND YOUTH AFFAIRS, DEETYA. (2000) Employer satisfaction with graduate skills, Evaluations and Investigations Programme, Higher Education Division, Research report 99/7 Australia February.

ENTWHISTLE, N. \& RAMSDEN, P. (1983) Understanding Student Learning. (London: Croom Helm).

FEELEY, T. (1976) Critical thinking towards a definition, paradigm and research agenda, Theory and Research in Social Education 1V August.

FEINER, S \& ROBERTS, B. (1995) Using Alternative paradigms to teach about race and gender: A critical thinking approach to introductory macroeconomics American Economic Review May: pp. 367-371.

HARASIM, L. HILTZ, S. TELES, L. TUROFF, M. (1997) Learning Networks: A field guide to teaching and learning online (Cambridge, Ma, MIT Press)

JOHNSTON C. JAMES, R. LYE J. MCDONALD I. (2000) An evaluation of the introduction of collaborative problem-solving for learning macroeconomics. Journal of Economic Education, 31, pp. 13-29.

JOHNSON, R.H. (1992) The problem of defining critical thinking in The generalizability of critical thinking: Multiple perspectives on an educational ideal (NY, SP Norris Ed Teachers College Press).

LAURILLARD D. (1993) Rethinking University teaching; A framework for the effective use of educational technology (London, Routledge). 
MARTON, F. \& SALJO, R. (1976) On qualitative differences in learning:1 - Outcomes and process'. British Journal of Educational Psychology, 46, pp. 4-11.

MARTON, F., HOUNSELL, D.J., AND ENTWISTLE, N.J. (1984) The Experience of Learning, (Edinburgh: Scottish Academic Press).

MCINNIS, C. \& JAMES, R. (1995) First year on campus study (Canberra, Australian Government Printing Service).

MEYER, C. \& JONES, T. (1993) Promoting Active learning: Strategies for the College Classroom (San Franscisco, Jossey-Bass).

PALINSCAR, A. \& BROWN, A. (1984) Reciprocal Teaching of ComprehensionFostering and Comprehension-Monitoring Activities, Cognition and Instruction, 2, $117-$ 175.

RAMSDEN, P. (1992). Learning to teach in higher education (London, Routledge London)

SLAVIN, R. (1990). Research on Co-operative Learning: Consensus and Controversy, Educational Leadership, Dec/Jan, pp. 52-54.

SOPER, J.C., WALSTAD, W.B. 1983 On Measuring Economic Attitudes, Journal of Economic Education, Fall, pp 4-17

Words: $\quad 6,773$ 


\begin{tabular}{|l|c|c|c|c|}
\hline \multicolumn{5}{|c|}{ TABLE I: Section 1: Pre and Post surveys } \\
\hline & \multicolumn{2}{|c|}{ Pre } & \multicolumn{2}{c|}{ Post } \\
\hline & Total & NESB & Total & NESB \\
\hline Total respondents & 1077 & $415(39 \%)$ & 1046 & $401(39 \%)$ \\
\hline 1. Male & $562(52 \%)$ & $201(48 \%)$ & $547(52 \%)$ & $159(47 \%)$ \\
\hline \multicolumn{1}{|c|}{ Female } & $515(48 \%)$ & $214(52 \%)$ & $497(48 \%)$ & $212(53 \%)$ \\
\hline 2. ESB & $662(61 \%)$ & - & $643(62 \%)$ & \\
\hline NESB & $415(39 \%)$ & - & $401(38 \%)$ & - \\
\hline $\begin{array}{l}\text { 3. Did Intro Micro in Semester 1 } \\
\text { 2000 }\end{array}$ & $960(89 \%)$ & $361(87 \%)$ & $923(88 \%)$ & $345(86 \%)$ \\
\hline $\begin{array}{l}\text { 5. In Semester 1 used Into Micro } \\
\text { home page (Pre). In semester 2 } \\
\text { used Intro Macro Internet home } \\
\text { page (Post). }\end{array}$ & & & & \\
\hline Never & $134(12 \%)$ & $41(10 \%)$ & $44(4 \%)$ & $17(4 \%)$ \\
\hline Sometimes & $665(61 \%)$ & $263(63 \%)$ & $433(42 \%)$ & $168(42 \%)$ \\
\hline Regularly & $288(28 \%)$ & $111(27 \%)$ & $567(54 \%)$ & $216(54 \%)$ \\
\hline $\begin{array}{l}\text { 6. If you used the Introductory } \\
\text { Microeconomics } \\
\text { (Macroeconomics) home page } \\
\text { did it improve your perception of } \\
\text { subject delivery? }\end{array}$ & & & & \\
\hline Yes & & & & \\
\hline No & $281(26 \%)$ & $252(61 \%)$ & $773(74 \%)$ & $306(76 \%)$ \\
\hline
\end{tabular}

Pre: beginning of semester survey

Post: end of semester survey

ESB English speaking background

NESB: Non English speaking background 


\begin{tabular}{|c|c|c|c|c|c|c|c|c|c|c|c|c|c|}
\hline & & Table & 1 & 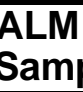 & $\begin{array}{l}\text { SUR } \\
\text { ple ar }\end{array}$ & $\bar{V}$ & ec & n & & & & & \\
\hline Rate your confiden & nce in & relat & on to & the ff & ollowi & ing sh & kills: & & & & & & \\
\hline Skills & $\begin{array}{l}\text { Alw } \\
\text { Conf } \\
\end{array}$ & $\begin{array}{l}\text { lays } \\
\text { fident } \\
\text { 4) }\end{array}$ & $\begin{array}{l}\text { Gen } \\
\text { Con }\end{array}$ & $\begin{array}{l}\text { erally } \\
\text { fident } \\
3 \text { ) }\end{array}$ & & $\begin{array}{l}\text { metim } \\
\text { s } \\
\text { onfide } \\
\text { (2) }\end{array}$ & & $\begin{array}{r}\text { Gen } \\
\mathrm{N} \\
\text { Conf } \\
(1\end{array}$ & $\begin{array}{l}\text { erally } \\
\text { ot } \\
\text { ident } \\
\text { 1) }\end{array}$ & $\begin{array}{l}\mathrm{Ne} \\
\text { Conf } \\
(0\end{array}$ & $\begin{array}{l}\text { ver } \\
\text { fident } \\
\text { 0) }\end{array}$ & $\mathrm{Me}$ & ean \\
\hline & pre & post & pre & pos & t pre & & ost & pre & Post & pre & post & pre & post \\
\hline ALL STUDENTS & $\%$ & $\%$ & $\%$ & $\%$ & $\%$ & & $\%$ & $\%$ & $\%$ & $\%$ & $\%$ & & \\
\hline $\begin{array}{l}\text { Pre-N=1077;Post } \\
N=1046\end{array}$ & & & & & & & & & & & & & \\
\hline $\begin{array}{l}\text { a) Computer related } \\
\text { skills }\end{array}$ & 19.3 & 26.5 & 45.4 & $48 . \varsigma$ & 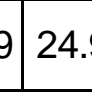 & & 0.2 & 8.3 & 3.9 & 2.1 & 0.6 & 2.71 & 2.97 \\
\hline $\begin{array}{l}\text { b) Internet related } \\
\text { skills }\end{array}$ & 19.6 & 28.2 & 45.2 & 48.6 & \begin{tabular}{l|l}
6 & 27. \\
\end{tabular} & & 8.8 & 6.2 & 3.7 & 1.5 & 0.7 & 2.75 & 3.00 \\
\hline $\begin{array}{l}\text { c) Critical thinking } \\
\text { skills }\end{array}$ & 10.9 & 12.8 & 41.6 & 44.7 & 736. & & 5.4 & 8.6 & 6.3 & 1.9 & 0.8 & 2.51 & 2.63 \\
\hline $\begin{array}{l}\text { d) Problem solving } \\
\text { skills }\end{array}$ & 11.6 & 12.3 & 40.1 & 42. & 437. & & 6.8 & 8.7 & 7.4 & 2.2 & 1.1 & 2.50 & 2.57 \\
\hline ESB & & & & & & & & & & & & & \\
\hline $\begin{array}{l}\text { Pre-N = 662; Post- } \\
N=646\end{array}$ & & & & & & & & & & & & & \\
\hline $\begin{array}{l}\text { a) Computer related } \\
\text { skills }\end{array}$ & 21.5 & 29.1 & 50.6 & $49 . \varepsilon$ & 820. & & 7.2 & 5.7 & 3.6 & 1.8 & 0.3 & 2.84 & 3.04 \\
\hline $\begin{array}{l}\text { b) Internet related } \\
\text { skills }\end{array}$ & 21.6 & 31.0 & 48.0 & 49. & \begin{tabular}{l|l}
1 & 24.
\end{tabular} & & 6.3 & 4.4 & 3.3 & 1.2 & 0.5 & 2.84 & 3.07 \\
\hline $\begin{array}{l}\text { c) Critical thinking } \\
\text { skills }\end{array}$ & 12.8 & 16.1 & 48.5 & 49. & \begin{tabular}{l|l}
4 & 32.
\end{tabular} & & 0.7 & 5.1 & 3.7 & 1.1 & 0.15 & 2.67 & 2.78 \\
\hline $\begin{array}{l}\text { d) Problem solving } \\
\text { skills }\end{array}$ & 14.0 & 15.3 & 45.8 & 47.5 & 532. & $\begin{array}{ll}.931 \\
\end{array}$ & 1.9 & 5.9 & 5.1 & 1.4 & 0.15 & 2.66 & 2.73 \\
\hline NESB & & & & & & & & & & & & & \\
\hline $\begin{array}{l}\text { Pre }-N=415 ; \text { Post }- \\
N=400\end{array}$ & & & & & & & & & & & & & \\
\hline $\begin{array}{l}\text { a) Computer related } \\
\text { skills }\end{array}$ & 15.9 & 22.5 & 37.1 & $47.3^{2}-x$ & $\begin{array}{lll}3 & 32 .\end{array}$ & \begin{tabular}{l|l|l|}
.525 \\
\end{tabular} & \begin{tabular}{l|l}
5.0 & 1 \\
\end{tabular} & 12.3 & 4.5 & 2.7 & 1.0 & 2.51 & 2.85 \\
\hline $\begin{array}{l}\text { b) Internet related } \\
\text { skills }\end{array}$ & 16.6 & 23.8 & 40.7 & $47 . \varepsilon$ & $\begin{array}{lll}8 & 31 .\end{array}$ & \begin{tabular}{l|l}
6 & 23 \\
\end{tabular} & 3.0 & 9.2 & 4.5 & 1.9 & 1.0 & 2.61 & 2.89 \\
\hline $\begin{array}{l}\text { c) Critical thinking } \\
\text { skills }\end{array}$ & 7.7 & 7.5 & 30.6 & 37.5 & \begin{tabular}{l|l}
3 & 44.
\end{tabular} & & 3.0 & 14.2 & 10.5 & 3.4 & 1.8 & 2.25 & 2.38 \\
\hline $\begin{array}{l}\text { d) Problem solving } \\
\text { skills }\end{array}$ & 7.7 & 7.5 & 31.1 & 34. & $\begin{array}{ll}0 & 44 .\end{array}$ & & \begin{tabular}{l|l}
4.8 & 1 \\
\end{tabular} & 13.3 & 11.0 & 3.6 & 2.8 & 2.26 & 2.33 \\
\hline
\end{tabular}




\begin{tabular}{|c|c|c|c|c|c|c|}
\hline \multicolumn{7}{|c|}{$\begin{array}{l}\text { Table III: CALM SURVEY Section } 3 \\
\text { (Mean scores) }\end{array}$} \\
\hline \multirow[t]{2}{*}{ Statement } & \multicolumn{2}{|c|}{ All } & \multicolumn{2}{|c|}{ ESB } & \multicolumn{2}{|c|}{ NESB } \\
\hline & Pre & Post & Pre & Post & Pre & Post \\
\hline \multicolumn{7}{|l|}{ Attitude to macroeconomics } \\
\hline 1) I enjoy reading articles about economic topics. & 2.24 & $2.51^{*}$ & 2.26 & $2.57^{*}$ & 2.20 & $2.40^{*}$ \\
\hline $\begin{array}{l}\text { 2) On occasion I read an unassigned book/article on } \\
\text { macroeconomics. }\end{array}$ & 1.84 & $2.04^{*}$ & 1.79 & $2.06^{*}$ & 1.93 & 2.02 \\
\hline 3) Macroeconomics is boring. $\psi$ & 1.51 & $1.36^{*}$ & 1.45 & $1.30^{*}$ & 1.60 & $1.47^{*}$ \\
\hline 4) I hate macroeconomics. $\psi$ & 1.21 & 1.15 & 1.13 & 1.07 & 1.34 & 1.29 \\
\hline 5) Macroeconomics is a difficult subject for me. $\psi$ & 2.14 & 2.14 & 2.10 & 2.06 & 2.20 & 2.26 \\
\hline 6) Macroeconomics is easy for me to understand. & 2.01 & 1.94 & 2.02 & 1.99 & 1.98 & 1.86 \\
\hline 7) Macroeconomics is one of my favourite subjects. & 2.04 & $2.18^{*}$ & 2.04 & $2.19^{*}$ & 2.05 & 2.15 \\
\hline 8) Studying macroeconomics is a waste of time. $\psi$ & 1.11 & $1.01^{*}$ & 1.01 & 0.92 & 1.27 & $1.15^{\star}$ \\
\hline 9) Macroeconomics is practical. & 2.74 & $2.83^{*}$ & 2.85 & 2.29 & 2.58 & $2.69^{*}$ \\
\hline \multicolumn{7}{|l|}{ Relevance } \\
\hline $\begin{array}{l}\text { 10) I can see the relevance of macroeconomics to } \\
\text { real world issues. }\end{array}$ & 3.09 & $3.20^{*}$ & 3.21 & $3.34^{*}$ & 2.90 & $2.99^{*}$ \\
\hline 11) I use macroeconomics to analyse situations. & 2.16 & $2.44^{*}$ & 2.08 & $2.36^{*}$ & 2.28 & $2.56^{*}$ \\
\hline \multicolumn{7}{|l|}{ Deep approach } \\
\hline $\begin{array}{l}\text { 12) I find it helpful to 'map out' a new topic in } \\
\text { macroeconomics for myself by seeing how the ideas } \\
\text { fit together. }\end{array}$ & 2.26 & 2.29 & 2.23 & 2.23 & 2.32 & 2.40 \\
\hline $\begin{array}{l}\text { 13) I generally put a lot of effort into trying to } \\
\text { understand things which initially seem difficult. }\end{array}$ & 2.69 & 2.63 & 2.68 & 2.60 & 2.71 & 2.69 \\
\hline $\begin{array}{l}\text { 14) I try to relate macroeconomics theory to real } \\
\text { situations }\end{array}$ & 2.50 & $2.73^{*}$ & 2.50 & $2.71^{*}$ & 2.51 & $2.75^{\star}$ \\
\hline $\begin{array}{l}\text { 15) I enjoy the intellectual challenge of } \\
\text { macroeconomics. }\end{array}$ & 2.48 & 2.51 & 2.49 & 2.51 & 2.48 & 2.52 \\
\hline \multicolumn{7}{|l|}{ Consistent work } \\
\hline $\begin{array}{l}\text { 16) I usually attempt all the work set for } \\
\text { macroeconomics tutorials. }\end{array}$ & 2.36 & 2.37 & 2.34 & 2.30 & 2.41 & 2.48 \\
\hline 17) I revise my macroeconomics work regularly. & 2.04 & 1.95 & 1.92 & 1.82 & 2.23 & 2.16 \\
\hline \multicolumn{7}{|l|}{ Collaboration } \\
\hline $\begin{array}{l}\text { 18) I regularly discuss macroeconomics with other } \\
\text { students. }\end{array}$ & 1.74 & $1.93^{*}$ & 1.64 & $1.85^{\star}$ & 1.89 & $2.07^{*}$ \\
\hline 19) I value what other students have to say in class. & 2.77 & $2.83^{*}$ & 2.76 & $2.83^{*}$ & 2.77 & 2.84 \\
\hline \multicolumn{7}{|l|}{ Feedback } \\
\hline $\begin{array}{l}\text { 20) I received sufficient feedback on my progress in } \\
\text { MICROeconomics (pre) / Macroeconomics (post) } \\
\text { last (pre) / this (post) semester. }\end{array}$ & 1.70 & $2.21^{*}$ & 1.61 & $2.22^{*}$ & 1.86 & $2.21^{*}$ \\
\hline
\end{tabular}

* indicates that the post mean score is significantly higher, at the 5 per cent level of significance, than the pre mean score based on a Mann-Whitney test for the null of equality of means versus the one-sided alternative that the post mean is higher than the pre mean score. $\psi$ means that a Mann-Whitney test for the null of equality of means versus the one-sided alternative that the post mean is smaller than the pre mean score was used ${ }^{*}$ indicates significance at the 5 per cent level). 


\begin{tabular}{|c|c|c|c|c|c|c|c|c|c|}
\hline \multicolumn{10}{|c|}{$\begin{array}{c}\text { Table IV: CALM Survey Section } 4 \\
\text { (\% of Sample and Means) }\end{array}$} \\
\hline \multicolumn{10}{|c|}{ Rate your agreement in relation to each of the statements: } \\
\hline Statement & $\begin{array}{l}\text { Definitely } \\
\text { Agree } \\
(4) \\
\% \\
\end{array}$ & $\begin{array}{l}\text { Definitely } \\
\text { Agree } \\
(4) \\
\% \\
\end{array}$ & $\begin{array}{l}\text { Agree } \\
(3) \\
\%\end{array}$ & $\begin{array}{l}\text { Uncer- } \\
\text { tain } \\
(2) \\
\% \\
\%\end{array}$ & $\begin{array}{c}\text { Dis- } \\
\text { agree } \\
(1) \\
\% \\
\end{array}$ & $\begin{array}{l}\text { Definitely } \\
\text { Disagree } \\
(0) \\
\% \\
\end{array}$ & Mean & $\begin{array}{l}\text { Mean } \\
\text { ESB }\end{array}$ & $\begin{array}{l}\text { Mean } \\
\text { NESB }\end{array}$ \\
\hline \multicolumn{10}{|l|}{ CALM } \\
\hline I found CALM easy to use & 21.9 & 21.9 & 59.0 & 10.9 & 6.8 & 1.4 & 2.93 & 2.96 & 2.88 \\
\hline $\begin{array}{l}\text { Help with CALM was easily } \\
\text { available. }\end{array}$ & 14.7 & 14.7 & 49.3 & 26.2 & 7.8 & 1.9 & 2.67 & 2.63 & 2.75 \\
\hline \multicolumn{10}{|l|}{ Consistent work } \\
\hline $\begin{array}{l}\text { CALM helped me work } \\
\text { consistently through the } \\
\text { semester. }\end{array}$ & 20.4 & 20.4 & 54.6 & 17.1 & 6.0 & 1.9 & 2.85 & 2.87 & 2.83 \\
\hline \multicolumn{10}{|l|}{ Relevance } \\
\hline $\begin{array}{l}\text { The economic issues raised } \\
\text { in CALM helped me to } \\
\text { understand the application of } \\
\text { economic theory to real world } \\
\text { economic issues. }\end{array}$ & 28.1 & 28.1 & 56.5 & 11.9 & 2.1 & 1.4 & 3.08 & 3.08 & 3.08 \\
\hline \multicolumn{10}{|l|}{ Skills } \\
\hline $\begin{array}{l}\text { I have improved my critical } \\
\text { analysis skills as a result of } \\
\text { commenting on the } \\
\text { responses of my peers. }\end{array}$ & 10.8 & 10.8 & 47.5 & 28.4 & 10.0 & 3.3 & 2.53 & 2.49 & 2.59 \\
\hline $\begin{array}{l}\text { I have improved my problem } \\
\text { solving skills during the } \\
\text { semester. }\end{array}$ & 8.3 & 8.3 & 49.6 & 33.3 & 7.4 & 1.4 & 2.56 & 2.54 & 2.60 \\
\hline \multicolumn{10}{|l|}{ Collaboration } \\
\hline $\begin{array}{l}\text { I learned from reading the } \\
\text { responses of my peers. }\end{array}$ & 10.4 & 10.4 & 49.1 & 23.7 & 12.3 & 4.4 & 2.49 & 2.41 & 2.62 \\
\hline $\begin{array}{l}\text { I valued the feedback I } \\
\text { obtained from the comments } \\
\text { of my peers }\end{array}$ & 8.2 & 8.2 & 51.6 & 23.2 & 11.8 & 5.2 & 2.50 & 2.38 & 2.60 \\
\hline
\end{tabular}




\begin{tabular}{|l|l|l|}
\hline \multicolumn{3}{|c|}{ Table V: Quality of Teaching Survey Results } \\
\hline Statement & $\begin{array}{c}\text { Subject } \\
\text { Mean } \\
\mathrm{N}=713\end{array}$ & $\begin{array}{c}\text { Department } \\
\text { first and } \\
\text { second year } \\
\text { Mean* } \\
\mathrm{N}=1925\end{array}$ \\
\hline 1) I had a clear idea of what was expected of me in this subject & 3.7 & 3.5 \\
\hline 2) This subject was well taught & 4.1 & 3.5 \\
\hline 3) This subject was intellectually stimulating & 4.0 & 3.5 \\
\hline 4) I received helpful feedback on how I was going in this subject & 3.5 & 3.0 \\
\hline $\begin{array}{l}\text { 5) In this subject teaching staff showed an interest in the academic needs } \\
\text { of students. }\end{array}$ & 3.8 & 3.5 \\
\hline 6) The multimedia based technology helped me to learn effectively & 4.1 & 3.7 \\
\hline 7) Using the web helped me to learn effectively & 4.0 & 3.7 \\
\hline $\begin{array}{l}\text { 8) I found it useful to access information and subject materials using the } \\
\text { subject web site }\end{array}$ & 4.0 & 3.4 \\
\hline $\begin{array}{l}\text { 9) This subject has improved significantly my understanding of the } \\
\text { discipline of macroeconomics }\end{array}$ & 4.1 & 3.6 \\
\hline
\end{tabular}

${ }^{*}$ The Department of Economics offers seven subjects in second semester of first year and second year. 


\section{University Library}

\section{- M M N E R VA A gateway to Melbourne's research publications}

Minerva Access is the Institutional Repository of The University of Melbourne

Author/s:

JOHNSTON, CAROL;OLEKALNS, NILSS

Title:

Enriching the learning experience: a CALM approach

Date:

2000-12

Citation:

Johnston, Carol and Olekalns, Nilss (2000) Enriching the learning experience: a CALM approach.

Persistent Link:

http://hdl.handle.net/11343/33643 